\title{
MATINYA KEPERCAYAAN AGAMA
}

\section{Abdul Wahid}

\author{
Judul: The End of Faith \\ Penulis: Sam Harris \\ Penerbit: W. W. Norton \& Company, New York, 2005 \\ Tebal: 348 halaman
}

Otoritas agama sebagai pembawa kedamaian, keberkahan, dan kesejahteraan bagi umat manusia dewasa ini semakin digugat. Kalangan filosof telah memberi preseden bagi gugatan itu. Agama dianggap tidak lagi sejalan dengan kehidupan modern yang rasionalistik. ${ }^{1}$ Nietzche, misalnya, dengan statemen "God is dead"-nya, menggugat agama dan kepercayaan umat manusia sebagai sesuatu yang sama sekali tidak menolong kehidupan dan karenanya ditinggalkan oleh para penganutnya. Karl Marx melihat agama hanyalah sekumpulan mitos-mitos metafisik yang meninabobokan dan seringkali menjadi alat untuk melegitimasi berbagai praktik penindasan sehingga agama tidak ubahnya candu bagi kehidupan. Pandangan skeptis terhadap agama terus berkembang mengikuti mainstream modernitas. Agama kemudian dibenturkan dengan rasionalisasi cara pandang terhadap segala aspek kehidupan, dan itu seringkali berakhir dengan keterpojokan posisi agama. Pada tataran filosofis, gugatan terhadap agama terjadi karena agama terkikis sedikit demi sedikit pijakan argumentatifnya oleh serbuan rasionalisme modern. Sementara pada tataran sosiologis, agama digugat karena

${ }^{1}$ Lihat misalnya, Peter Angeles (ed.), Critiques of God: A Major Statement of the Case Against Belief in God (Buffalo: Promotheus Books, 1976). 
kehilangan elan vitalnya sebagai entitas pembangunan masyarakat di satu sisi dan keterlibatannya yang intens dalam berbagai praktik penindasan, konflik, dan kekerasan.

Distorsi makna dan fungsi agama ini kemudian melahirkan banyak argumen, terutama di kalangan sarjana Barat. Mereka melihat agama memiliki karakter (nature) yang sangat kuat sebagai sumber legitimasi berbagai tindakan, baik, atau buruk, maslahat atau mudlarat, perdamaian atau kekerasan. Bahkan, menurut Kurtz, semua agama besar memiliki pembenaran yang merupakan akar bagi tindakan kekerasan. ${ }^{2}$

"The use of religious arguments to justify violence waxes and wanes historically, but few justifications of violence are as universally upheld as those supported by the world's religious traditions. In the religious context, violence is usually done in the name of some good, and often in the name of God". 3

Dalam karya Harris ini diyakini, bahwa aspek dalam agama yang menjadi sumber kekerasan itu, tidak lain adalah kepercayaan (faith) yang menjadi fondasi setiap agama. Hal ini dikarenakan sistem kepercayaan dianggap oleh para penganutnya sebagai sesuatu yang suci dan harus "diamini” sehingga kepercayaan mau tidak mau merupakan mesin penggerak segala sikap dan perilaku keagamaan, baik itu sikap dan perilaku yang berdimensi ritual, maupun yang berdimensi sosial. Pertanyaannya, bagaimana agama dibelokkan fungsinya sebagai sumber inspirasi kebenaran dan kedamaian menjadi sumber legitimasi tindakan kekerasan?

Banyak kalangan percaya, penyimpangan fungsi agama dari penebar kedamaian dan kesejahteraan sebagai penebar ancaman dan kekerasan tidak bersebab tunggal, dalam pengertian sematamata bersumber dari aspek kepercayaan agama. Banyak aspek

${ }^{2}$ Lester Kurtz, Gods in the Global Village (California: Pine Forge Press, 1995), 215.

I Ibid. 
lain yang menjadi determinan dalam kekusutan wajah agama, antara lain masuknya unsur-unsur politik di dalamnya. Masuknya unsur politik dalam agama karena disadari agama memiliki karakter sebagai pembangkit dan perekat kesadaran kolektif, pemicu solidaritas, dan pembangkit emosi, lebih dari entitas lain seperti bahasa, ras, dan kebangsaan. Maka, tidak heran jika agama kemudian menjadi sangat ideologis. Karena itu, agama sangat fungsional dan terbuka bagi masuknya kepentingankepentingan, terutama politik sehingga terjadi fenomena "politisasi agama".

Tesis politisasi agama inilah yang dibantah oleh Harris dengan buku ini. Aspek kepercayaan yang inheren dalam agamalah sumber utama kekerasan atas nama agama. Semua agama memang mengalami persoalan dan represi politikekonomi, tetapi penyikapannya bisa berbeda-beda dari masingmasing agama. Orang Kristen Palestina, misalnya tidak mengambil tindakan bom bunuh diri sebagaimana rekan muslim mereka, padahal mereka sama-sama mengalami kekejaman pendudukan Israel. Demikian juga kaum Budha Tibet yang tidak bertindak apa-apa terhadap kekejaman Cina. Ada memang motivasi politik dan ekonomi di dalam tindakan kekerasan seperti yang terjadi di Irak misalnya, tetapi politik dan ekonomi tidak bisa membuat orang seberani seorang anak muda yang menghancurkan dirinya dengan bom di kerumunan anak-anak, atau membuat ibunya bernyanyi bangga atas tindakan anaknya. Menurut Harris, tindakan sedahsyat ini biasanya dilandasi oleh "kepercayaan" dalam agama. ${ }^{4}$ Itulah keajaiban keyakinan yang melahirkan kesadaran individu dan kolektif yang irrasional, atau dalam istilah Harris, reason in exile, kehilangan akal sehat. Ada satu bukti utama yang disampaikan Harris untuk memperkuat

${ }^{4}$ Sam Harris, The End of Faith (New York: W. W. Norton \& Company, 2005), 234. 
argumennya, bahwa kepercayaanlah yang menciptakan kekerasan, misalnya Osama bin Laden.

Namun demikian, tidak semua penganut kepercayaan memiliki potensi untuk mampu melakukan tindakan-tindakan destruktif di luar akal sehat. Keyakinan yang "berkarat" dan ekstrim yang seringkali mengiringi tindakan ekstrim, biasanya diadopsi oleh kelompok-kelompok keagamaan fundamentalisekstremis. ${ }^{5}$ Mereka mengambil ajaran dari kitab suci secara literal, dan ini mendorong mereka untuk bersikap ekstrem. Hanya saja sikap dan tindakan mereka bertitik tolak dari kritisisme terhadap fenomena-fenomena kontemporer terutama terhadap modernitas. Ini karena dalam konteks kepercayaan mereka, bahwa modernitas dan budaya sekuler tidak sesuai dengan nilai moral dan spiritual. ${ }^{6}$

Karena itulah, menurut Harris, kekerasan dalam agama bukan semata-mata berkaitkelindan dengan aspek sosial, politik, dan ekonomi, tetapi juga di dalam diri agama itu sendiri terdapat ajaran-ajaran mengenai kekerasan. Hal ini semakin tampak jika teks-teks suci itu berada di genggaman para penganut ekstrem agama. Perpaduan antara keyakinan yang kuat dan sikap skripturalis terhadap kitab suci melahirkan tindakan ekstremisme yang sering di luar jangkauan akal sehat.

Kepercayaan yang mendalam dan pembacaan teks yang serba tekstual inilah, menurut Harris, biang segala tindak kekerasan atas nama agama. Tesis ini diperkuat dengan argumen-argumen logis-filosofis serta akademik, terutama berkenaan dengan keyakinan. Secara neurosaintis, bidang kajian Harris, kepercayaan merupakan landasan bagi aksi. "Beliefs are principles of action; whatever they may be at the level of the brain, they are processed by

${ }^{5}$ Dalam kasus Islam sekarang, istilah fundamentalisme atau ekstremisme sudah jarang digunakan dan sebagai gantinya adalah Islamisme. Lihat Oliver Roy, Genelogi Islam Radikal, ter. Nasrullah Ompu Bana (Yogyakarta: Genta Press, 2005).

'Harris, The End..., 29. 
which our understanding (and misunderstanding) of the world is represented and made available to guide our behavior". ${ }^{7}$

Keyakinan itu kemudian melandasi tindakan. Itulah sebabnya, kini keyakinan tidak lagi dipandang sebagai sesuatu yang pribadi, tetapi juga sebagai konsep publik. Karena tindakan yang dilandasi oleh keyakinan tertentu bisa menimbulkan efek sosial yang sangat besar, baik itu tindakan kebaikan ataupun tindakan buruk.

Latar belakang akademik Harris yang jebolan filsafat dari Stanford University memberi bobot bagi argumen-argumen di atas. Selama dua puluh tahun, dia mempelajari tradisi-tradisi agama Timur dan Barat, khususnya pada berbagai disiplin spiritual. Apalagi dia mendalami neuroscience yang mempelajari basis neural dari fenomena kepercayaan, ketidakpercayaan, dan keagamaan. Dengan latar belakang akademik ini, tulisan Harris dalam buku ini tentu diharapkan memiliki bobot akademik yang cukup tinggi.

Buku ini diawali dengan sebuah ilustrasi, suasana peledakan bom bunuh diri oleh seorang anak muda di sebuah bis. Peledakan itu menghancurkan seluruh isi bis termasuk diri pelaku sendiri. Meski sedih, ibu sang anak berbangga dan terharu karena dua kemenangan diraih oleh sang anak, yaitu anaknya bakal masuk surga dan ia bisa menghancurkan sang musuh dan mengirim mereka ke neraka. Absurd, tetapi itulah kepercayaan atau keyakinan. "A belief is a lever that, once pulled, moves almost everything else in a person's life". 8

Pada bagian kedua, buku ini berbicara basis-basis teoritis mengenai kepercayaan. Aspek-aspek mendasar seputar kepercayaan muncul di sini, seperti koherensi logis mengenai kepercayaan sebagai dasar tindakan, kepercayaan sebagai representasi dunia, kepercayaan dan bukti-buktinya, kepercayaan

${ }^{7} I b i d \ldots, 52$.

${ }^{8}$ Ibid, 12. 
dan kegilaan, dan apa saja yang semestinya menjadi materi suatu kepercayaan.

Pada bagian ketiga, buku ini mengungkap akar-akar historis kekerasan dalam agama. Dikatakan, praktik kekerasan dalam agama mula-mula muncul ketika kalangan gereja membungkam kalangan penginkar dokrin-dokrin gereja seperti yang terjadi pada gerakan Catharisme dan Manicheanisme. Melalui mekanisme inkuisisi, kalangan gereja mengontrol ketat praktikpraktik keagamaan, bahkan tidak segan membasmi penganut kepercayaan lain dengan cara kekerasan, seperti merajam dan membakar hidup-hidup. Perlakukan kekerasan atas nama Tuhan seperti ini terutama dialami oleh Negara-negara Yahudi dan kaum Semitis lainnya. Dengan gerakan anti-Semitisme, gereja mengobarkan permusuhan terutama kepada kalangan Yahudi yang mereka percayai sebagai biang terbunuhnya Yesus. Fenomena ini kemudian melahirkan berbagai horor (teror) dalam sejarah pertemuan penganut agama-yang fenomenal di antaranya adalah tragedy holocaust.

Pada bagian keempat, Harris secara khusus mengelaborasi berbagai problem terkait dengan Islam. Pada bagian ini dibicarakan mengenai cara pandang Islam terhadap dunia, pilihan gerakan, reaksi Islam dalam bentuk jihad, hubungannya dengan Barat yang cenderung berbenturan, totalitarianisme Islam, serta agenda-agenda ke depan seperti dialog, promosi demokrasi, dan mulkulturalisme.

Pada bagian kelima, disinggung mengenai determinasi gagasan keagamaan terhadap kebijakan-kebijakan Barat, khususnya Amerika Serikat. Ide-ide eksatologi telah merambah ke politik modern dan itu menunjukkan bahayanya kepercayaan agama. Jutaan kaum kristen dan muslim mengkoordinir diri mereka masing-masing dalam lingkaran tradisi-tradisi kenabian yang berujung pada tumpah ruahnya darah, seperti yang terjadi di Jerusalem. Kaum fundamentalis Kristen menopang Israel karena mereka percaya bahwa konsolidasi kekuatan Yahudi di 
Jerusalem merupakan langkah awal kembalinya Yesus, di samping prakondisi bagi kehancuran kaum Yahudi untuk terakhir kalinya. Demikian juga, banyak kebijakan pemerintah Amerika berbasiskan agama, semacam politik moralitas atau perang terhadap dosa.

Pada bagian keenam, Harris kembali berbicara basis saintifik mengenai etika, khususnya berkenaan dengan baik dan buruk. Dalam hal ini, Harris berbicara mengenai hubungan kesadaran dengan etika, termasuk etika beragama, komunitas moral, relativitas moral, intuisi, hubungan moralitas dengan kebahagiaan, dan kesalahan pilihan pada pasifisme.

Pada bagian terakhir, Harris membahas mengenai kesadaran yang antara lain; pengertian kesadaran, pencarian kebahagiaan melalui spiritualitas dan mistisme, ke"aku"an, kebijaksanaan Timur, dan meditasi. Bagian ini merupakan tawaran alternatif Harris tentang cara pandang terhadap dunia.

\section{Insipirasi Kitab Suci}

Keyakinan yang mendalam dan cara pandang terhadap dunia, terutama kepada aspek metafisik dan rahasia, bukan semata-mata produk dinamika intuitif. Ia muncul atas stimulasi informasi kitab-kitab suci. Kitab suci bisa memberi inspirasi sikap dan tindakan, termasuk tindakan-tindakan kekerasan. Tindakan kekerasan atas nama agama bukan semata-mata buman error, kesalahan manusia menerapkan firman-firman suci. Menurut Harris, kitab suci secara eksplisit menganjurkan tindakantindakan kekerasan, seperti bunuh diri atas nama Tuhan. Sebutlah konsepsi dan ajaran jihad dalam kasus Islam yang bersumber dari firman suci. Dalam teks-teks suci Islam, alQur'an dan hadis, misalnya, jihad secara gamblang dianjurkan dan bagi pelakunya diberi ganjaran kebahagiaan di akhirat kelak. Jihad sendiri secara etimologis (lughah) bermakna berjuang atau upaya keras, tetapi kemudian diasosiasikan kepada perang suci, yakni perang demi menegakkan dan membela agama Tuhan. 
Dalam praktiknya, jihad telah melahirkan fakta mempertahankan Islam dengan senjata dan berdarah-darah, baik kolosal maupun individual. Pada gilirannya tugas jihad bergeser menjadi upaya transformasi dunia dengan kaidah-kaidah penaklukan dan meniscayakan kekerasan, penggunaan pedang, atau bom; bagi para pelakunya, keberhasilan tugas itu merupakan prestasi yang amat besar.

"To see the role that faith plays in propagating muslim violence, we need only ask why so many muslims are eager to turn themselves into bombs these days, the answer: because the Koran makes this activity seem like a career opportunity". ?

Banyak ditemukan teks-teks mengenai prinsip dan kabar gembira jihad, yang oleh kalangan Islamis digunakan untuk menjustifikasi penyerangan terhadap kalangan lain yang kafir dengan cara kekerasan. Sebutlah misalnya sugesti-sugesti seperti: "berperang sehari semalam di medan perang lebih baik dari berpuasa dan shalat selama sebulan"; "Siapa yang meninggal tanpa ikut berperan dalam penyebaran agama meninggal dalam keadaan kafir"; "Surga itu di bawah bayang-bayang mata pedang".

Benturan bersenjata dalam mempertahankan agama bagi kalangan muslim tertentu menjadi kewajiban keagamaan yang harus ditunaikan. Jihad bahkan bukan saja sebagai upaya pertahanan diri jika Islam diserang oleh pihak lain, melainkan juga merupakan instrumen ekspansi terus menerus sampai titik darah penghabisan dalam rangka menjadikan seluruh dunia ini mengadopsi keyakinan Islam, atau mengakui kekuasaan Islam. Karena itu, konsepsi jihad seperti inilah yang paling menimbulkan masalah di kalangan nonmuslim.

Dengan berpegang teguh pada teks-teks itu, para pelaku kekerasan terkadang mengabaikan aspek-aspek politik, sosial, dan ekonomi sebagai motif terjadinya sebuah aksi. Atau dengan

${ }^{9}$ Ibid, 33. 
kata lain, tindakan-tindakan kekerasan seolah-olah tidak perlu memiliki justifikasi historis apapun, atau tidak didahului oleh sebab-sebab yang bersifat politik, sosial, dan ekonomi; semuanya murni didasarkan atas pemahaman ataupun keyakinan yang diadopsi dari kitab suci.

\section{Masalah dengan Islam}

Pembahasan mengenai Islam tampaknya menjadi pusat perhatian Harris dengan bukunya ini. Tetapi pada bagian ini pula, bobot ilmiah karya ini ternodai oleh sikap bias dan subjektifitas penulisnya melihat fenomena dalam dunia Islam.

"We are at war with Islam. It may not serve out immediate foreign policy objectives for our political leaders to openly acknowledge this fact, but it is unambiguously so. It is merely that we are at war with an otherwise peaceful religion that has been "hijacked" by extremists. We are at war with precisely the vision of life that is prescribe to all muslims in the Koran, and further elaborated in the literature of the hadith, which recounts the sayings and actions of the Prophet". ${ }^{10}$

Meski mengakui banyak-bahkan arus utama-kalangan moderat dalam Islam yang tidak respek pada militansi agama, Harris tetap melihat Islam sebagai "agama penakluk". Ia berpijak pada cara pandang Islam terhadap dunia yang terbagi dua, "house of Islam" (dâr al-Islâm) dan "bouse of war" (dâr al-barb) yang melahirkan konsekuensi logis pada sikap muslim terhadap orang lain yang tidak seiman. Sikap itu ialah pilihan antara memasukkan orang lain dalam agama Islam, mengontrol mereka, atau membunuh. Tidak ada perdamaian abadi dalam Islam karena Islam pada dasarnya tidak mengakui pihak lain, kecuali berbagi kekuasaan secara temporer dengan mereka yang notabene "musuh-musuh Tuhan".

Bagi Harris, pandangan dunia seperti itu sangat eksklusivistik dan penuh dengan klaim-klaim kebenaran. Bagi satu kalangan,

$$
{ }^{10} \mathrm{Ibid}, 109 .
$$


kalangan sendiri itulah yang benar, sementara kalangan yang lain adalah kafir. Berpijak dari keyakinan itu, muncullah praktikpraktik pemanggilan orang lain ke jalan yang dianggap benar tadi. Di kalangan tertentu pemeluk agama, sikap monopoli kebenaran seperti ini seringkali muncul karena perbedaan latar belakang pihak lain dinegasikan. Pada saat dua pihak yang memiliki sikap yang sama berhadap-hadapan, maka itulah awal mula kekerasan atas nama agama.

"It is no accident that people of faith often want to curtail the private freedoms of others. This impulse has less to do with the history of religion and more to do with logic, because the very idea of privacy is incompatible with the existence of God". 11

Pandangan berciri fundamentalis tersebut terutama tumbuh subur di kalangan muslim yang bergelut secara intens dengan Barat. Mereka ini melihat bahwa aksi-aksi politik dan militer terhadap Barat adalah intrinsik dengan praktik-praktik kepercayaan. Pandangan seperti ini muncul terutama karena fakta bahwa imperialisme dianggap sebuah dosa besar yang diperbuat oleh Barat terhadap dunia, khususnya terhadap dunia Islam. Karena itu dalam pandangan kaum fundamentalis, penaklukan dunia oleh Islam merupakan tugas yang suci dan niscaya. Pandangan seperti ini juga melegitimasi kaum muslim untuk menakluk dan menguasai Eropa, sekaligus memaksa mereka menganut kepercayaan dan agama yang benar.

"While there are undoubtedly some "moderate" muslims who have decided to overlook the irrescindable militancy of their religion, Islam is undeniably a religion of conquest The only future devout muslims can envisage - as muslims - is one in which all infidels have been converted to Islam, subjugated, or killed. The tenet of Islam simply do not admit of anything but a temporary sharing of power with the "enemies of God."12

${ }^{11}$ Ibid, 159 .

${ }^{12}$ Ibid, 110. 
Kekerasan atas nama agama merupakan tindakan balas dendam atas kriminalitas dan dosa Barat yang menakluk dan menguasai Islam. Dalam persepsi kaum muslim, berpindah ke Islam adalah keberkahan bagi pelaku dan prestasi besar bagi yang mengajak. Sebaliknya, dalam hukum Islam keluar dari Islam adalah kemurtadan, yang halal darahnya baik yang pelaku maupun bagi yang mengajaknya keluar dari Islam.

\section{Suatu Komentar}

Tulisan Harris ini terkesan tidak komprehensif, terutama dalam melihat fenomena-fenomena dalam Islam. Ia hanya menyorot sisi normatif agama, yakni teks-teks al-Qur'an dan hadis sementara wilayah-wilayah fenomenologis, tidak disentuh sama sekali. Harris cenderung mengenyampingkan fakta-fakta penindasan politik, ekonomi, dan imperialisme, yang dialami oleh umat Islam yang bersumber dari Barat, sebagai titik tolak dalam melihat fenomena munculnya praktik-praktik militansi Islam, terutama di dunia Barat. Karena pengabaian ini, maka tampaknya tulisan Harris sangat tipikal Barat, didasari prasangka buruk dan persepsi yang salah terhadap Islam.

Sebenarnya kekerasan dalam Islam adalah reaksi dan bukan aksi. Pada buku ini, Harris mengatakan lebih sebagai aksi yang tidak dilatarbelakangi oleh sebab-sebab sosial, politik, dan ekonomi yang jelas, selain hanya sebagai manifestasi kepercayaan semata-mata. Argumen Harris berangkat dari pengalaman umat Budha di Tibet dan kaum Kristen di Palestina. Kedua komunitas itu walaupun ditindas oleh Cina dan Israel, mereka tidak melakukan tindakan-tindakan destruktif seperti bom bunuh diri dan praktik-praktik teror ataupun yang lainnya, seperti ketika orang Islam diperlakukan sama.

"Where are the Palestinian Christian suicide bombers? They, too, suffer the daily indignity of the Israeli occupation. Where for that matter, are the Tibetan Buddhist suicide bombers? The Tibetans have suffered an occupation far more cynical and repressive than any that the United 
States of Israel has ever imposed upon the muslim world. Where are the throngs Tibetans ready to perpetrate suicidal atrocities against Chinese noncombatants? They do not exist. What is the difference that makes the difference? The difference lies in the specific tenets of Islam". ${ }^{13}$

Tentu di sini yang terabaikan oleh Harris, adalah melakukan penelusuran historis mengenai akar-akar peristiwa-peristiwa kekerasan, sebagaimana yang dilakukan dengan sangat baik oleh Ford ${ }^{14}$ atau Grant. ${ }^{15}$ Dengan membaca Ford, kita diajak untuk menengok kembali peristiwa-peristiwa kekerasan atas nama agama atau doktrin tertentu yang dirunut sejak zaman Yunani sampai zaman modern sekarang. Dari situ, kita dapat menarik kesimpulan bahwa sebenarnya kekerasan bukan merupakan monopoli agama atau peradaban tertentu, ia merupakan milik semua sejarah umat manusia. Bagi Ford, selama ada "politicing" dalam sejarah kehidupan manusia, maka selama itu pula konflik dan benturan akan menyertai. Demikian juga Grant, ia tidak serta merta memberi kesimpulan akan adanya potensi kekerasan dalam agama tertentu yang memanifes dalam bentuk yang destruktif. Ia menunjukkan titik-titik singgung terutama antara Islam dan Barat dalam lintasan sejarah. Lagi-lagi, politiklah yang determinan dalam pengalaman perbenturan antara Islam dan Barat. Jika fakta-fakta mengenai imperialisme dan penindasan Barat terhadap Islam dipertimbangkan sebagai basis sosial gerakan Islam, maka Harris akan menemukan tesis lain di seputar praktik kekerasan atas nama agama.

Di satu sisi, buku ini berupaya mengajukan argumen bahwa kepercayaan sebagai dasar kekerasan dalam Islam, tetapi di sisi lain dia mengatakan bahwa moral development yang cepat

${ }^{13}$ Ibid, 233.

14 Franklin L. Ford, Political Murder: From Tyrannicide to Terorism (Cambridge: Harvard University Press, 1985).

${ }^{15}$ George Grant, The Blood of the Moon: Understanding the Historic Struggle Between Islam and Western Civilization (Nashville: Thomas Nelson Publisher, 2001). 
berkembang menjadikan sebuah masyarakat lebih gampang menghindari dan meminimalisasi kekerasan. Harris juga memandang, seakan-akan hanya agama yang membuat orang tidak toleran. Kenyataannya, ketidakadilan, dan intoleran bisa terjadi karena berbagai perbedaan, ras, etnis, dan lain-lain. "Without faith, desperate people would still do terrible things. Faith it self is always and everywhere, exonerated". ${ }^{16}$

Menafikan aspek sosial, politik dan ekonomi dalam melihat fenomena kekerasan dalam komunitas agama sangat tidak memadai. Kalau kepercayaan sebagai satu-satunya faktor kekerasan dalam Islam, tentu semua orang Islam akan berideologi dan melakukan praktik yang sama. Kenyataannya tindakan-tindakan kekerasan selalu bersifat parsial, kasuistik, dan tidak melibatkan mayoritas Islam. Selain itu, kepercayaan juga selalu berinteraksi dengan faktor-faktor profan lainnya yang tentu saja tidak bisa secara sederhana dikesampingkan.

Banyak kekerasan yang terjadi dalam sejarah justru dilakukan oleh orang-orang atheis. Harris berargumen bahwa orang-orang tersebut bukanlah atheis yang rasional. "I know of no society in buman history that ever suffered because its people became too reasonable". ${ }^{17}$ Di titik ini, sebenarnya ia mementahkan sendiri argemennya yang menuduh keyakinan atau kepercayaan sebagai satu-satunya faktor karena sebenarnya ia menempatkan rasionalitas sebagai faktor penentu utama. Agama jika dijalankan dengan sikap yang rasional tentu akan menjadi lain.

Buku ini secara keseluruhan merupakan salah satu cermin cara pandang Barat yang cenderung bias terutama terhadap Islam. Meskipun dikemas dalam kajian dengan pendekatan saintik-akademik, tetap saja tidak bisa disembunyikan niat para penulis Barat untuk mendiskreditkan Islam melalui efektivitas media massa. Namun demikian, buku ini tetap penting paling

${ }^{16}$ Harris, The End..., 13.

${ }^{17}$ Ibid, 231. 
tidak sebagai bahan mengaca diri dan renungan atas peristiwaperistiwa kekerasan yang terjadi atas nama agama, terutama dalam Islam.

\section{Daftar Pustaka}

Franklin L. Ford, Political Murder: From Tyrannicide to Terorism (Cambridge: Harvard University Press, 1985).

George Grant, The Blood of the Moon: Understanding the Historic

Struggle Between Islam and Western Civilization (Nashville:

Thomas Nelson Publisher, 2001).

Lester Kurtz, Gods in the Global Village (California: Pine Forge Press, 1995).

Oliver Roy, Genelogi Islam Radikal, ter. Nasrullah Ompu Bana (Yogyakarta: Genta Press, 2005).

Peter Angeles (ed.), Critiques of God: A Major Statement of the Case Against Belief in God (Buffalo: Promotheus Books, 1976).

Sam Harris, The End of Faith (New York: W. W. Norton \& Company, 2005). 